Historic, Archive Document

Do not assume content reflects current scientific knowledge, policies, or practices. 



\title{
SPRING, 1922
}

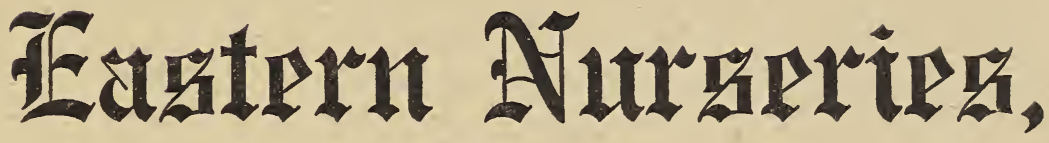

\author{
כึกrarparated
}

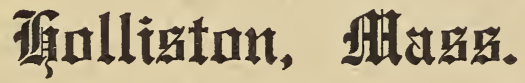

\section{PRICE LIST}

Discount of $20 \%$

from prices in this list to Landscape Architects and Park and Cemetery Superintendents.

Address all communications to EASTERN NURSERIES, INC., HOLLISTON, MASS.

Telephone, Natick 345

Telegraph Address, Natick, Mass. 

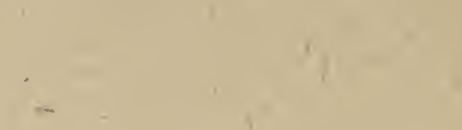


\section{SPRING, 1922 Eastern Nurseries, Inc. Office and Nurseries, HOLLISTON, MASS.}

SHIPPING SEASON opens about March 20 to April I in the Spring, and continues until May 20 to June $I$, and opens about October $\mathrm{I}$ in the Fall, and continues until the ground freezes. Shipping for summer planting of Evergreens opens about August I5th, Pot-grown plants can be shipped and planted at all times.

ORDERS.-Write plainly and give explicit directions as to address and mode of shipment; otherwise we will forward according to our best judgment. All goods travel at purchaser's risk. We assume no responsibility for the goods after delivery to the forwarding companies.

When losses occur by delays in delivery, claims should be made at once on the forwarding companies.

CLAIMS, to receive consideration, must be made within ten (10) days of receipt of goods.

While we exercise the greatest care to have all Trees, Shrubs and Plants genuine and reliable, and hold ourselves prepared to replace, on proper proof, all that prove untrue, we do not give any warranty, expressed or implied; and in case of an error on our part, it is mutually agreed between the purchaser and ourselves that we shall not at any time be held responsible for a greater amount than the original price of the goods.

PACKING.-We take great care in packing, using damp moss to protect roots. Boxes and bales are charged for at cost.

RATES.-The prices in this list supersede all previous rates, and apply to quantities specified, but two hundred and fifty 250) will be furnished at the thousand rate, twenty-five (25) at the one hundred rate, and five (5) at the ten rate.

This Price List cancels all previous lists and prices are subject to change without notice.

TERMS, CASH WITH ORDERS, except to such persons as satisfy us as to their responsibility. Bills are due when presented and interest will be charged at the rate of six per cent. on bills remaining unpaid December $\mathrm{I}$ in Fall and June $I$ in Spring.

A Certificate of Inspection will accompany each shipment.

Address all communications to office.

\section{EASTERN NURSERIES, INC.,}





\section{PRICE LIST \\ OF}

\section{Eastern Nurseries, Inc.}

William F. Dawson, President

Henry S. Dawson, Vice-President

L. B. Dawson, Sec.-Treas.

Office and Nurseries at HOLLISTON, MASS.

Located twenty-six miles southwest of Boston.

\section{SPRING, 1922}

Our Evergreens are in especially fine condition this year. Most of them have been transplanted recently and all of them are in excellent condition for August planting. We wish to call special attention to our small Evergreens suitable for hedges, group planting and window-boxes, and to our large specimens for immediate effects.

A cordial invitation is hereby extended to visit our nursery at any time for the purpose of plant study, or for inspection of saleable stock. EASTERN NURSERIES, INC.

\section{EVERGREEN TREES AND SHRUBS}

The prices of Evergreens include the burlapping of balls.

Abies balsamea Balsam Fir

Each $\quad 10 \quad 100$

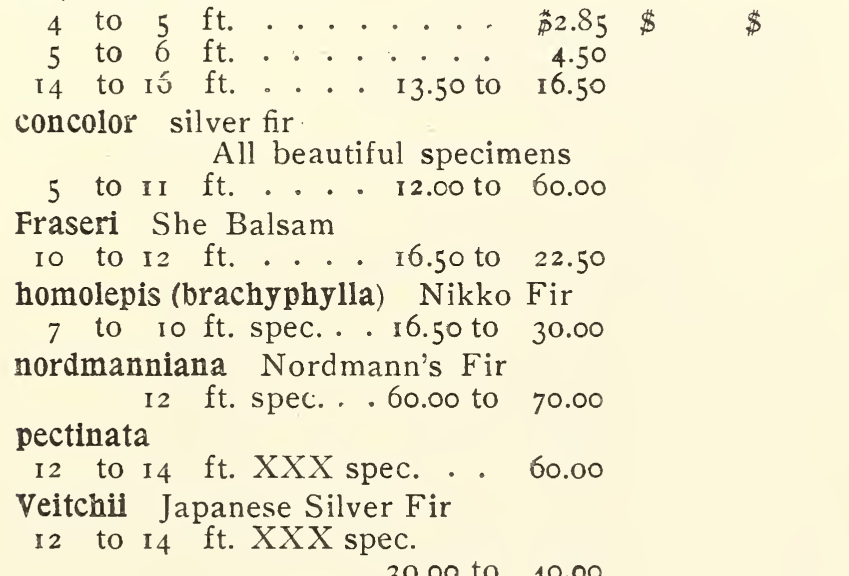


Andromeda floribunda See Pieris

Each

10

100

Euonymus radicans acutus Narrow-leaved Euonymus

$\begin{array}{lllll}3 & \text { yr. str. f. g. - . . } ~ & \$ .85 & \$ 8.00 & \$ \\ 3 \text { yr. str. pot-grown } & .85 & 8.00 & 70.00\end{array}$

carrieri Broad-leaved Euonymus

3 yr. strong . . . $\quad .50 \quad 4.00$

vegetus Round-leaved Euonymus

3 yr. strong. . . . $\quad .50 \quad 4.00 \quad 35.00$

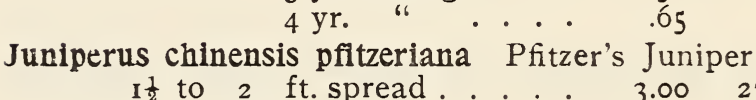

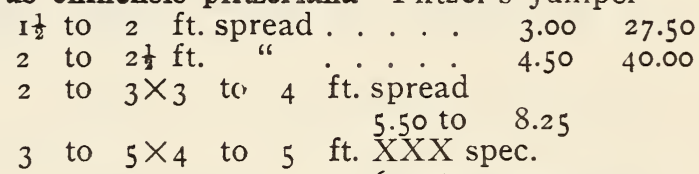

I6.50 to 27.50

procumbens Prostrate Juniper

I 5 to 18 in. spread .... 2.50

I8 to 24 in spread .... 3.00

communis Upright Juniper

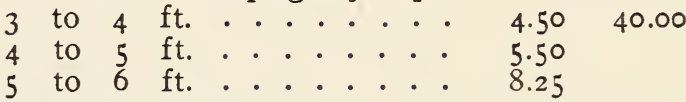

Note. The upright Juniper is one of the very hardiest evergreens, and one of the most satisfactory for the New England climate. It keeps its color all winter, and fruits when still quite small.

depressa Common Spreading Juniper
18 to 24
in. spread ....
$1.65 \quad 15.50$
24 to 30
in. spread
2.50

suecica Swedish Juniper

3 to $4 \mathrm{ft}$....... 3.85

4 to $5 \mathrm{ft}$. . . . . . 5.50

horizontalis Trailing Juniper

I5 to 18 in. spread .... $2.50 \quad 22.50$

18 to 24 in. spread . . . . 3.8536 .00

sabina tamariscifolia Tamarisk-leaved Juniper

2 to $3 \mathrm{ft}$. spread .... 5.00 virginiana Red Cedar

6 to 7 ft. . . . . . . . 9.00

7 to $8 \mathrm{ft}$. tr. IoI9 ... II.50

8 to $9 \mathrm{ft}$. tr. I9I9 ... I6.50

9 to Io $\mathrm{ft}$. tr. I9I9 . . . 22.50

Io to $30 \mathrm{ft}$. XXX spec. 35 to I 15.00

virginiana glauca Blue Cedar

5 to $6 \mathrm{ft} . \ldots . . . .8 .50$

6 to $7 \mathrm{ft}$....... 13.50

7 to $8 \mathrm{ft}$ tr. $1919 \ldots . . .16 .50$

8 to $9 \mathrm{ft}$ tr. I9I9 ... 22.50

9 to ro ft. tr. I9I9 ... 30.00

Note. The Blue and Red Cedars listed above have been growing in our own nurseries and are beautiful specimens recently transplanted and in perfect condition for moving this spring. 
Juniperus virginiana keteleeri

Each

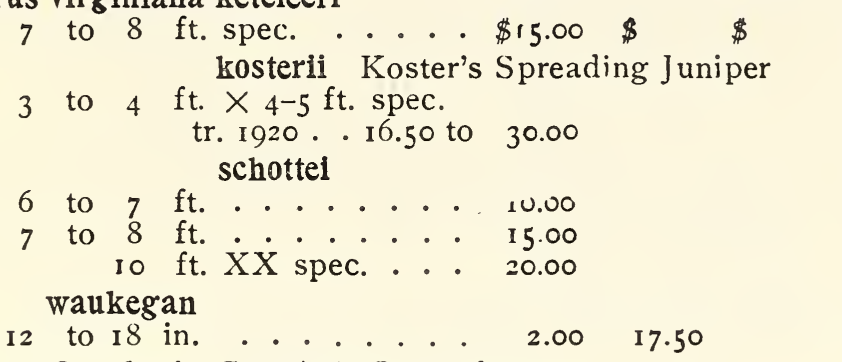

Leucothoe Catesbaei Catesby's Leucothoe 18 in. clps. . . 2.2520 .00

Picea albertiana Alberta Spruce

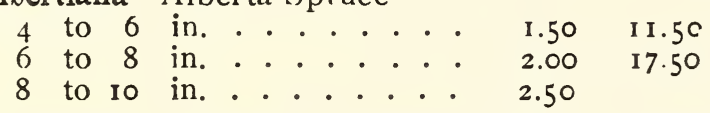

A charming symmetrical evergreen, which grows so so slowly that it will stay in scale for many years. We have a large stock of this desirable novelty.

alcockiana Alcock's Spruce

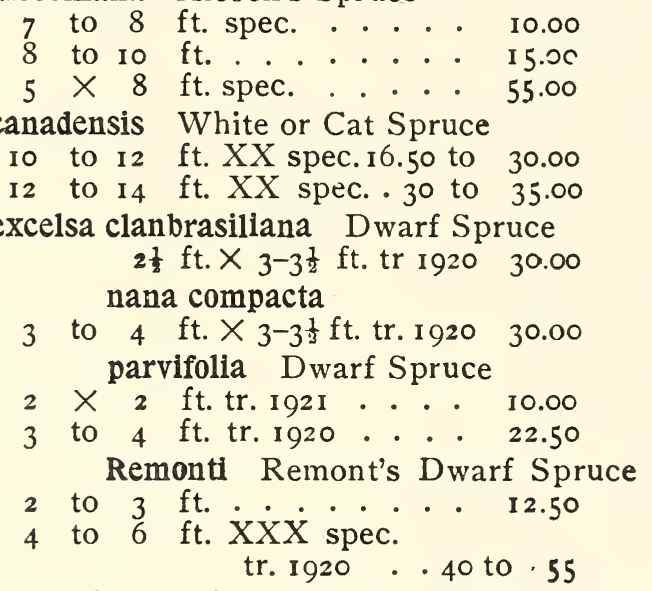

Note. Some of our Dwarf Spruce are wonderful specimens, and most of them have been moved within a year. For formal notes or for the foreground of Evergreen plantings these plants are admirably adapted orientalis Oriental Spruce 5 to $6 \mathrm{ft}$. broad... Io to I2.50 pungens Green Colorado Spruce

6 to $7 \mathrm{ft}$ tr. $1920 \ldots 10.00$

7 to 8 ft. spec. tr. 1920 . . I 2.00

8 to io ft.spec. tr. 1920 I 5 to 30.00

glauca Colorado Blue Spruce

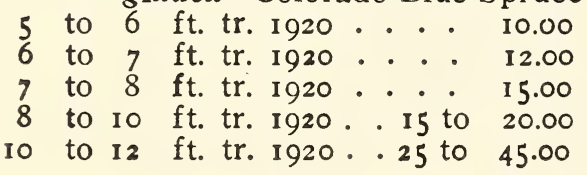


Picea pungens kosteri Koster's Blue Spruce

\section{Each}

$$
\begin{aligned}
& 5 \text { to } 6 \mathrm{ft} \text {. tr.pl. I920... \$I3.75 \$ \$ } \\
& 6 \text { to } 7 \mathrm{ft} \text {. } 6 \text { "6... } 15.50 \\
& 7 \text { to } 8 \mathrm{ft} \text {. "6 " . . . } 20.00 \\
& 8 \text { to ro ft. " " } 22.50 \text { to } 30.00
\end{aligned}
$$

All our specimens of Colorado Spruce, both the Blue forms and the Green forms, were transplanted a year ago and are now in an ideal condition for planting in permanent places.

Pieris (Andromeda) floribunda Mountain Fetter Bush

$*_{2}$ to $3 \mathrm{ft} . \times 2-3 \mathrm{ft}$. XXX spec.

$$
16.50 \text { to } 22.50
$$

Pinus cembra Swiss Stone Pine

$$
\begin{aligned}
& 2 \text { to } 3 \mathrm{ft} \text {. . . . . . } 4.0030 .00
\end{aligned}
$$

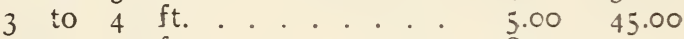

$$
\begin{aligned}
& 4 \text { to } 5 \mathrm{ft} \text {...... } 8.0075 .00 \\
& 6 \text { to Io ft. XX spec. } 16.50 \text { to } 5500
\end{aligned}
$$

The Swiss Stone Pine is one of the most beautiful of all pines for formal work. The tree is very slow growing, consequently is important for use as accents where one wishes an accent which will stay in scale for many years. Our plants are all beautiful specimens.

\section{flexilis Limber Pine}

$$
2 \text { to } 3 \mathrm{ft} \text {. . . . . } 3.00 \quad 25.00
$$

montana mughus Mugho or Dwarf Mountain Pine

$$
\begin{aligned}
& 2 \mathrm{ft} \times 2 \frac{1}{2} \mathrm{ft} \text {. spread } \quad 4.00 \\
& 2 \frac{1}{2} \mathrm{ft} \text { to } 3 \mathrm{ft} \text {. spread }
\end{aligned}
$$

strobus White Pine

$$
5.50 \text { to } 8.25
$$

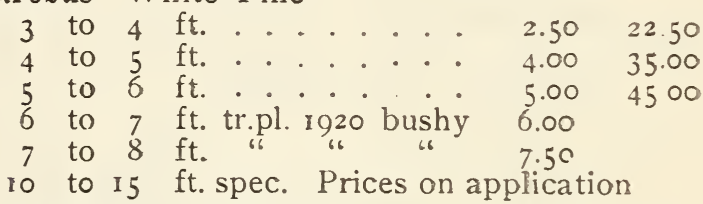

sylvestris Scotch Pine

8 to 10 ft. spec. ... 16.50

I0 to $12 \mathrm{ft}$. spec. . . . 22.50

Pseudolarix kaempferi Japanese False Larch 5 to $6 \mathrm{ft}$. spec. . . I 1.50 to 16.50

Pseudotsuga douglasi Douglas Spruce

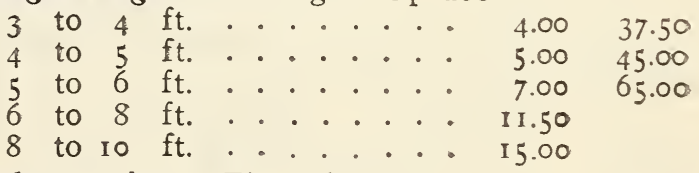

Pyracantha coccinea Fire Thorn

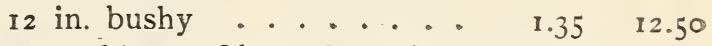

Retinospora obtusa Obtuse-leaved Japanese Cypress

3 to $3 \frac{7}{2} \mathrm{ft} . \ldots \ldots 50$

\section{magnifica}

3 ft. broad .... 6.00

pisifera Pea-fruited Japanese Cypress

$2 \frac{1}{2}$ to $3 \mathrm{ft}$...... 3.00

8 to $10 \mathrm{ft}$.... 16.50 to 22.50 
Retinospora pisifera aurea Golden Japanese Cypress

Each 10

100

2 to $3 \mathrm{ft} . \ldots . \ldots . . . \$ 3.00 \$$

3 to $4 \mathrm{ft} . \ldots . . . .30$

6 to $7 \times 5 \mathrm{ft}$. spec. . . . II.50

7 to $8 \times 6 \mathrm{ft}$. spec. 13.75 to 16.50

filifera Thread-branched

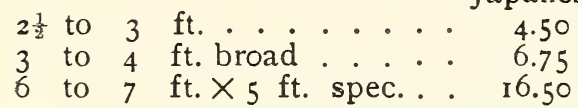

Japanese Cypress

plumosa Plume-like Japanese Cypress

2 to $3 \mathrm{ft} \cdot \mathrm{ft} \cdot 3.50 \quad 30.00$

6 to $8 \mathrm{ft} . \times 5-6 \mathrm{ft} . \mathrm{XX}$ spec. $\quad 16.50$

Io to I4 ft. $\times 5-6 \mathrm{ft}$. spec. 30 to 55.00

aurea Golden Plume-like

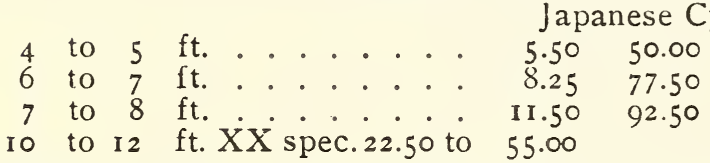

Rhododendron hybrids, all well budded plants, imported spring, rgrg.

Album Elegans Blush white

$$
\begin{aligned}
& 2 \text { ft. . . . . } 5.00 \\
& 2 \frac{1}{2} \mathrm{ft} . \ldots . .60
\end{aligned}
$$

Charles Dickens Scarlet early

$$
\begin{aligned}
& 2 \mathrm{ft} \text {. . . . . . } 5.00 \\
& 2 \frac{1}{2} \mathrm{ft} \text {. . . . . } 6.60 \\
& 3 \text { ft. heavy . . . } 9.30
\end{aligned}
$$

Everestianum Rosy lilac early

$2 \mathrm{ft}$. . . . . 5.00

Grandiflorum 3 Clear rose

$$
2 \mathrm{ft} . \text {..... } 5.00
$$

Kettledrum Rich crimson

$$
2 \mathrm{ft} \text {..... } 5.00
$$

Memoir White with blush

$$
2 \mathrm{ft.} \text {. . . . . } 5.00
$$

Mrs. Charles S. Sargent Pink

$$
2 \mathrm{ft} \text {...... } 5.00
$$

Roseum elegans Deep rosy pink

$$
\begin{aligned}
& 2 \mathrm{ft} \text {. heavy ... } 6.60 \\
& 3 \text { ft. heavy . . . I II.50 }
\end{aligned}
$$

We also have some fine specimens grown in our own nurseries of Abraham Lincoln, Album elegans, Charles Dickens, Delicatissimum, Everestianum, President Lincoln, Purpureum elegans and Roseum elegans.

3 to $4 \frac{1}{2} \mathrm{ft}$. bushy spec. I6 to 30.00

laetevirens (wilsonianum) Wilson's Rhododendron

$$
\begin{aligned}
& \text { I } 5 \text { in. } X 15-18 \text { in. . } 5.00 \\
& 18 \text { in. } X 1 \frac{1}{2} 2 \mathrm{ft} . . .6 .60
\end{aligned}
$$


Rhododendron maximum Great Bay

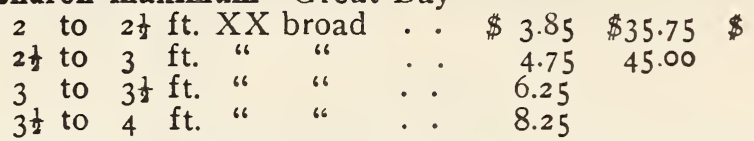

COLLECTED CLUMPS F.O.B. our shipping point in Pennsylvania in carload lots.

$$
\begin{aligned}
& 2 \text { to } 5 \mathrm{ft} \text {. mixed clumps at } \$ 45^{\circ} \text { per carload } \\
& 5 \text { to } 7 \mathrm{ft} \text {. XXX broad specimen clumps }
\end{aligned}
$$

Prices on application

We make a specialty of collecting Rhododendron Maximum in carload lots. The plants vary in size from $I$ to $5 \mathrm{ft}$. From $\sigma_{5}$ to 350 plants can be put into a car, depending upon the size of the plants. We ship only first class plants.

Taxus baccata repandens Spreading Yew

I 5 to 18 in. spread compact 2.00

canadensis Canadian or Ground Yew

8 to 12 in. . . . . . I I.40 II.50

12 to 18 in. $\times 18-24$ in. . . $3.00 \quad 27.50$

cuspidata Japanese Yew

$\mathbf{I 2}$ to 18 in. $X 18$ in. spread . $3.85 \quad 33.00$

$\mathrm{I} \frac{1}{2}$ to $2 \mathrm{ft} . \times 18-24$ in. spread $5.50 \quad 50.00$

I $\frac{1}{2}$ to $2 \mathrm{ft}$. $\times 2-2 \frac{1}{2} \mathrm{ft}$. spread $8.25 \quad 77.00$

Our Taxus cuspidata are all heavy plants, recently transplanted. We believe there is no finer stock of this indispensable Evergreen in this country.

nana (brevifolia) Dwarf Japanese Yew

8 to 12 in....... $275 \quad 22.50$

I to $1 \frac{1}{2} \mathrm{ft}$........ $3.85 \quad 33.00$

densa Compact Dwarf Japanese Yew

8 to 12 in...... 3.50

12 to 15 in...... 4.50

Thuya occidentalis American Arbor Vitæ

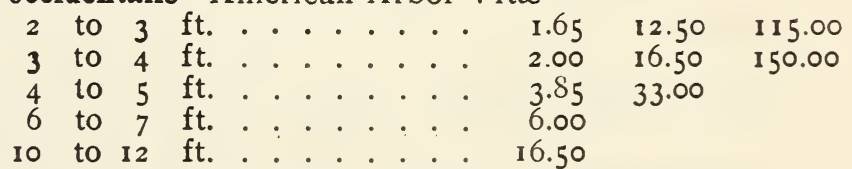

Io to $12 \mathrm{ft}$ buchanani Buchanan's Arbor Vitae

5 to $6 \mathrm{ft}$. heavy specimens 12.00

8 to $8 \mathrm{ft}$ "

8 to $9 \mathrm{ft}$. "

ellwangerlana Ellwanger's Arbor Vitæ

I to $1 \frac{1}{4} \mathrm{ft} . \ldots . . . .1 .65$

2 to $3 \mathrm{ft} . \times 3-3 \frac{1}{2} \mathrm{ft}$. 5 to 7.50

George Peabody George Peabody's

Golden Arbor Vitæ

15 to 18 in. . . . . . . $1.00 \quad 7.2566 .00$

2 to $2 \frac{1}{8} \mathrm{ft}$. ....... 2.50

4 to $7 \mathrm{ft}$. spec. . . 6 to 12.00 


\section{Each}

100

Thuya occidentalis globosa Globe Arbor Vitæ

$$
\begin{aligned}
& 12 \text { in. } X \mathrm{I} 2 \text { in..... } \$ 1.40 \$ 11.50 \quad \$ \\
& 15 \text { in. } X{ }_{5} \text { in.... } 1.65 \quad 14.00 \\
& 18 \text { in. } X 18 \text { in. ... } 2.00 \quad 16.50 \\
& 2 \text { to } 3 \text { ft. } \times 2-3 \mathrm{ft} \text {. spec. . } 6.60 \\
& 3 \text { to } 4 \text { ft. } \times 3-4 \text { spec. . . } \\
& 8.25 \text { to } 1 \mathrm{I} .50
\end{aligned}
$$
I6.50 to 30.00

Hoveyl Hovey's Golden Arbor Vitæ

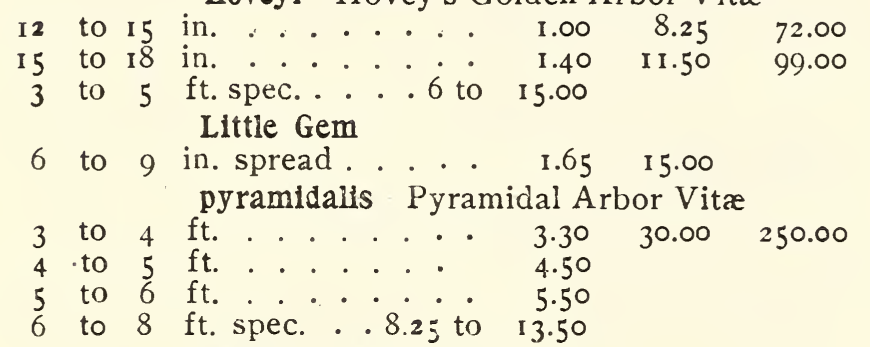

Rledil Ried's Arbor Vitae

I to If ft. ....... $2.00 \quad \mathrm{I} 6.50$

2 to $3 \mathrm{ft} . . . \cdots \quad 3.30 \quad 30.00$

4 to 5 ft. XX heavy spec. 16.50 vervaeneana Vervaen's Arbor Vitae

2 to $3 \mathrm{ft} . \ldots \ldots . .3 .00 \quad 25.00$

6 to $9 \mathrm{ft}$. heavy spec. I 2 to 22.50

warreana (sibirica) Siberian Arbor Vitæ

3 to $3 \frac{1}{2} \mathrm{ft} . \ldots . . .24 .50$

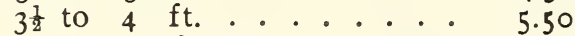

4 to 5 ft. spec. . . 8.25 to II.50

5 to $7 \mathrm{ft}$. XX spec.16.50 to 22.50

\section{Waxen}

5 to $6 \mathrm{ft}$. $\times 3^{-5} \mathrm{ft} \mathrm{spec}$.

$$
40 \text { to } 55.00
$$

These plants are very old and are beautiful specimens

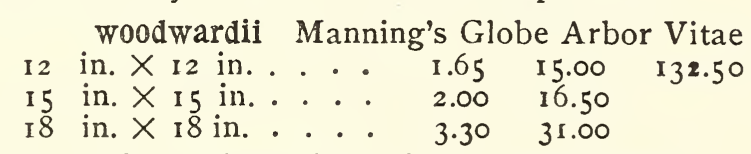

Most of our Arbor Vitaes have been transplanted within the last two years, and are in prime condition for hedges or specimens.

Isuga canadensis American Hemlock

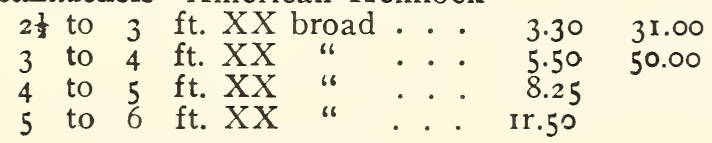

Our Hemlocks, too, have been transplanted recently and all are beautiful broad specimens.

pendula Sargent's Weeping Hemlock

I2 to 18 in. $\times 2-3 \mathrm{ft}$. I I.5O to 15.00 


\section{LIST OF POT-GROWN PLANTS}

Which can be shipped and planted at all times

\begin{tabular}{|c|c|c|c|}
\hline \multicolumn{4}{|l|}{ Abelia rupestris Arbutus Shrub } \\
\hline $\begin{array}{c}\text { Adella rupestris Arbutus Shrub } \\
2 \frac{1}{2} \text { in. pots . . . }\end{array}$ & $\$ .80$ & $\$ 7.00$ & $\$$ \\
\hline 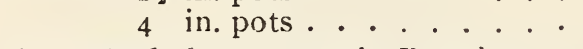 & 1.25 & 10.00 & 85.00 \\
\hline rctostaphylos uva-ursi Bear-berry & & & \\
\hline 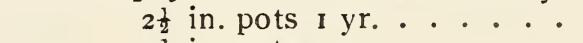 & .45 & 3.75 & 30.00 \\
\hline $2 \frac{1}{2}$ in. pots 2 yr. & .70 & 6.00 & 45.00 \\
\hline $2 \frac{1}{2}$ in. pots $3 \mathrm{y}$ r. strong. . . & .95 & 8.75 & 66.00 \\
\hline $\begin{array}{l}4 \text { in. pots heavy } \ldots . \\
\text { erennis }\end{array}$ & I.25 & 10.00 & 90.00 \\
\hline . . . . . & .35 & 2.50 & 18.00 \\
\hline
\end{tabular}

Berberis verruculosus Evergreen Barberry

4 in. pots 3 yr. .... 3.00

Calluna vulgaris Scotch Heather, and named varieties

Scotch Heather, the "Bonnie Purple Heather" of song and verse, is a lovely, low-growing evergreen shrub, 6 in to $3 \mathrm{ft}$. in height. of the Heath Family, covered in midsummer with small, bell shaped purple flowers, borne on slender spikes. These flowers stay in good condition for some weeks, and if cut while fresh will hold their color and charm all winter. Honey bees, too, are attracted to Scotch Heather and make from it a honey that is consifered very choice. This plant is widely known as invaluable for planting in full sun in sandy soil: it is also most attractive as an edging to beds of Rhododendrons, Laurel, etc., and in Rock Gardens. This little plant gives most satisfaction when planted from pots. Besides the common purple Heather there are many varieties which give variation in the height of plant, color of flowers. and season of bloom. Below we offer a list of varieties, all of which are pot grown, sturdy plants. $2 \frac{1}{3}$ in. pots

var. alba White Scotch Heather, early blooming, with light green foliage, white flowers, grows 12 to 15 inches. $2 \frac{1}{2}$ and 3 in. pots

var. alba elata Tall White Heather. Late blooming, very tall, straight growth. Foliage soft dark green, fowers white, grows 18 to 24 in. 21 and 3 in. pots

var. alba hammondii Hammond's White Heather. Midseason, tall upright growth, foliage rich deep green, flowers white, grows 18 to 24 in. high. $2 \frac{1}{2}$ and 3 in. pots

var. alba minor Small-leaved White Heather. Mid-season, tall bushy growth, 15-20 in. high, foliage very fine light green; flowers white. 3 in. pots

var. alba pilosa Late blooming, tall growth $18-20$ in. high, foliage of soft grayish green, flowers white. 3 in. pots.

var. alba rigida Late, low rigid growth, foliage rich deep green, flowers white. $2 \frac{1}{2}$ and 3 in. pots

var. alportil Late blooming, tall straight growth to $24 \mathrm{in}$. foliage deep rich green, turning purple in autumn. Flowers rosy carmine. $2 \frac{1}{2}$ and 3 in. pots

var. aurea Golden foliage and pink flowers, one of the best of those with colored foliage. $2 \frac{1}{2}$ in. pots 
var. compacta Late blooming. Low compact, moss-like growth, 4 to 6 in. high, of bright, rich green. Flowers pale lavender. $2 \frac{1}{2}$ and 3 in. pots

var. cuprea Mid-season. Straight medium growth I2 to $I_{5}$ in. high, foliage bright, almost yellowish green, turning to rich glowing red in autumn. Flowers purple $2 \frac{1}{2}$ and 3 in. pots

var. humilis Low growing, with rich green foliage. Flowers, midseason. white. 3 in. pots

var. hypnoides Late blooming. Low-spreading growth, 6 to 12 in. high. Foliage soft deep green, flowers deep pink. 3 in. pots

var. monstrosa Loose growth. Flowers pink. 3 in. pots

var. rubra Early blooming, with low spreading growth, 6 to 12 in. high. Foliage soft green turning purple in autumn. Flowers rosy carmine. $2 \frac{1}{2}$ and 3 in. pots

var. hirsuta (tomentosa) Midseason. Low compact growth 4 to $;$ in. high, foliage soft gray, flowers purple. $2 \frac{1}{2}$ and 3 in. pots

var. tenella $2 \frac{1}{2}$ in. pots

var. variegata "Has white leaves interspersed with the normal green ones." Flowers pale lavender 3 in. pots Prices on Heather and varieties:

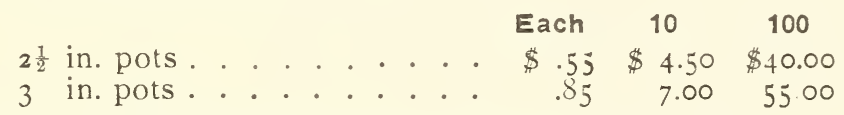

Note: The Cotoneasters are among the most important groups of hardy plants which have recently been brought before the public. All of them have attractive foliage and conspicuous berries. Of those listed below C. adpressa, horizontalis and its variety perpusilla, and C. microphylla are of low-spreading growth, have small glossy, evergreen-like foliage and bright red berries which stay on the shrubs well into the winter. The plants of this group of Cotoneaster are particularly adaptable for use in rockery, on the edge of low shrubberies or on slopes. C. Dielsiana, divaricata and salicifolia floccosa are of more shrub-like growth, with long graceful branches, glossy leaves and bright red berries. All of these plants are hardy and do well in any good well-drained garden soil, but require plenty of water during the first year after transplanting, and take hold much more satisfactorily when transplanted from pots than from the field.

Cotoneaster adpressa

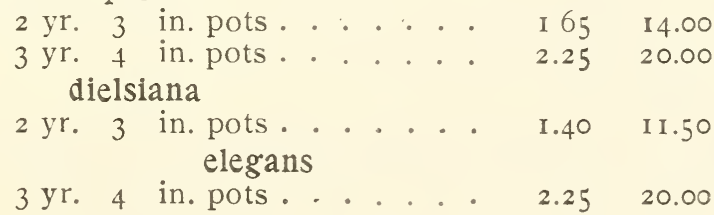


Cotoneaster divaricata

Each $10 \quad 100$

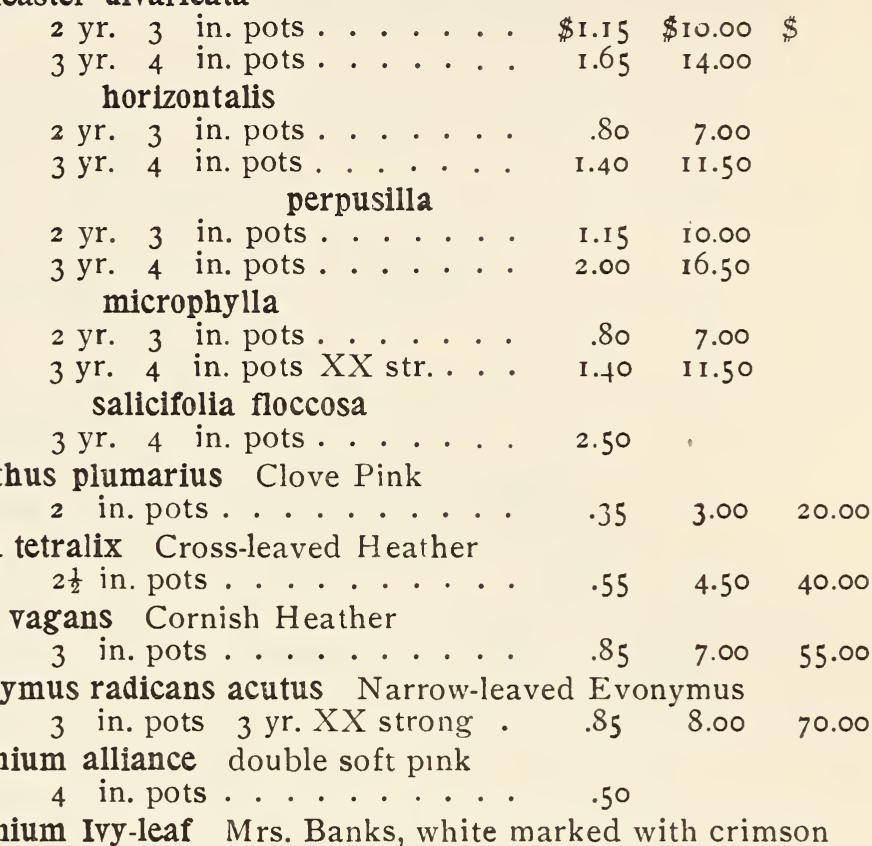

Dianthus plumarius Clove Pink

Erica tetralix Cross-leaved Heather
4 in. pots
Roycroft Surprise double

4 in. pots........ .50

5 in. pots . . . . . . . $.75 \quad 6.00$

The Ivy-leafed Geraniums are splendid plants for hanging baskets or conservatory boxes.

Hedera helix English Ivy

3 in. pots....... $50 \quad 4.00$

Hypericum calycinum Rose of Sharon

$2 \frac{1}{2}$ in. pots....... . . . . $40 \quad 3.50 \quad 30.00$

Lonicera japonica henryi

3 in pots............. $75 \quad 6.00$

nitida Evergreen Honeysuckle

A tall-growing, graceful shrub, with long slender branches thickly clothed with small shining evergreen leaves which turn rich purple in the autumn. This beautiful shrub is not quite hardy in the vicinity of Boston; but for southern New England, Long Island, New York and south and west it should prove a valuable garden hedge plant.

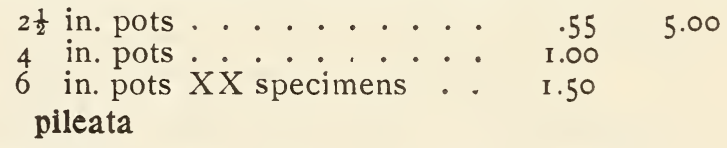

This Honeysuckle, also, is evergreen. The growth of this shrub is somewhat stiff, and spreading, the foliage $\frac{1}{2}$ to 1 inch long, rather box-like, and bright shining green. While still a small plant L. pileata is covered with small yellow 
flowers which produce in early autumn beautiful transparent berries of clear light purple. Like L. nitida this shrub dees not always survive the severe winters of this climate; but in southern New England and south and west it is one of the most useful and beautiful of the new shrubs. It will serve as a specimen shrub in the garden, a shrub for rockgardens, or as a low, wide-spreading hedge.

Pachistima canbyi

$$
\begin{aligned}
& \text { Each } 10 \quad 100 \\
& 4 \text { in. pots........ \$1.00 \$8.50\$ } \$ \\
& 6 \text { in. pots ......... } 1.50 \quad \text { I } 3.50
\end{aligned}
$$

$2 \frac{1}{2}$ in. pots 2 yr. . . . . . . $55 \quad 500 \quad 45.00$

3 in. pots 3 yr. . . . . . $\quad .70 \quad 5.50 \quad 50.00$

Pachysandra terminalis Japanese Spurge

$2 \frac{1}{2}$ in. pots ... \$122 per M $1.65 \quad 14.00$

$2 \frac{1}{2}$ in. pots X strong \$I $\$ 50$ per M $\quad 2.00 \quad 18.00$

Phlox subulata alba White Ground Phlox

$2 \frac{1}{2}$ in pots . . . . . . $\quad .35 \quad 3.25 \quad 25.00$

G. F. Wilson Lavender Ground Phlox

2 in. pots....... $\quad 3.25 \quad 25.00$

Potentilla tridentata

2 in. pots XX strong ... $\quad \begin{array}{llll}35 & 3.25 & 25.00\end{array}$

Rose American Pillar Climber of strong growth with rich glossy foliage and huge clusters of large, cherry-colored flowers

$$
3 \text { in. pots ........ . . . } 75 \quad 6.00
$$

Apple Blossom A Dawson hybrid, of rambler habit like the Dawson Rose, but with clear shell-pink flowers Early

*4 in. pots . . . . . . I.75

Rosa Alberic Barbier A wichuraiana hybrid climber; glossy foliage and large deep cream flowers late in June

$$
3 \text { in. pots....... } .756 .00
$$

Dawson A Dawson hybrid climber of rambler habit. Flowers semi-double deep pink in large clusters. Early
3 in pots
$.60 \quad 5.00$
4 in. pots XX strong . . . $\quad .75 \quad 6.00$

Daybreak A Dawson hybrid. Climber with glossy foliage and large clusters of single deep salmon pink flowers in July

$$
4 \text { in. pots....... I. I.00 } 7.50
$$

Dr. Van Fleet Strong growing climber with glossy foliage and large double shell pink flowers in early July
3 in. pots ........ .85

4 in. pots....... I.I5

excelsa Climbing wichuraiana hybrid bearing clusters of double brilliant red flowers late in season

$$
3 \text { in. pots........ } 75 \quad 6.00
$$

gallica grandiflora Low bush of spreading habit, with rich foliage, young growth deep red. Flowers large, single pink and very early

$$
3 \text { in. pots.......... I. } 135 \text { I2.50 }
$$

Harrison Old-fashioned yellow Rose

3 in. pots....... $1.35 \quad 10.00$ 


\section{Each $10 \quad 100$}

Rosa Helenae Shrub with slender branches and large clusters of pure white fragrant flowers. Considered by the Arnold Arboretum one of the handsomest of all roses brought from China by Mr. Wilson

$$
4 \text { in. pots...... \$2.25\$ \$ }
$$

Hugonis Father Hugo's Rose. An upright rose with stems covered in early spring witn single clear yellow flowers before the foliage appears

$$
4 \text { in. pots...... } 2.00 \quad 17.50
$$

hibernica gravesil Irish Rose. Single flowered pink rose closely related to the Scotch Rose
4 in. pots
I. 50

Lady Duncan A Dawson hybrid, semi-climber, with rich green rugosa-like foliage, and large clear salmon-pink flowers, blooming in late June. Absolutely free from injurious pests

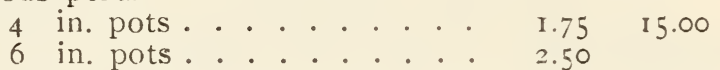

Lady Gay Pink climber much like Dorothy Perkins
4 in. pots
$.75 \quad 6.00$

Mme. Plantier Old-fashioned double flowered white rose
3 in. pots.......
$.75 \quad 6.00$

Minnie Dawson Dawson hybrid. Rambler of the Dawson habit, the flowers small double white borne in large clusters

$$
4 \text { in. pots....... } 1.75
$$

multiflora catheyensis The pink multiflora from China

$$
3 \text { in. pots.......... I.00 } 7.50
$$

Pauline Dawson A Dawson hybrid climber or pillar rose of good foliage and large single deep pink flowers
3 in. pots.
t. 25

penzance hybrids Bush roses, hybrids of the popular Sweet Briar, having fragrant pink flowers

$$
4 \text { in. pots............. I.25 } 10.00
$$

rugosa repens alba Climbing or creeping white-flowered rugosa hybrid, with glossy foliage and large star-shaped white flowers

$$
3 \text { in. pots.......... I.25 } 10.00
$$

Sargent The loveliest of a!l the Dawson Hybrids. A strong growing bush or pillar rose, having good glossy foliage and great clusters of large semi-double pink flowers, at its perfection in late June

$$
4 \text { in. pots....... I.75 }
$$

seashell Dawson hybrid. Climber which has glossy foliage and large clusters of large semi.double pink flowers, blooming in July
3 in. pots...... I. I. .
4 in. pots ....... 1.50

Silver Moon Climber with glossy rich foliage and large single cream white flowers, blooming in July
6
in. pots
I.00
$7 \cdot 50$

spinosissima Scotch Briar

3 in. pots....... $1.00 \quad 8.00$ 
Each 10

100

Rosa Tausendschon Climber. Good foliage, flowers large, shell pink fading to white. Late bloomer. July 4 in. pots...... \$I.75\$6.00\$

William C. Egan A Dawson hybrid, climber, with good foliage and large very double pink flowers. Late June
3 in. pots.
.75
6.50
I.00
$7 \cdot 50$

4 in. pots.

Look under shrubs for list of our field grown Roses

Sedum acre Stonecrop $2 \frac{1}{2}$ in. pots strong $\begin{array}{llllll} & . & 30 & 2.50 & 18.00\end{array}$

Silene maritima $2 \frac{1}{2}$ in. pots............ $30 \quad 2.50 \quad$ I 8.00

Vaccineum vitis-idaea Mountain Cranberry $3 \frac{1}{\frac{1}{2}}$ in. pots heavy ..... $85 \quad 6.00 \quad 50.00$ Veronica rupestris $2 \frac{1}{1}$ in. pots strong ....... $\quad .30 \quad 2.50 \quad 18.00$

Vinca alba 2 years $2 \frac{1}{2}$ in. pots . . . . . . . $40 \quad 3.50 \quad 30.00$

minor 2 years $2 \frac{1}{2}$ in. pots . . . . \$120 M $\quad .25 \quad 2.00 \quad 15.00$

Viola atropurpurea $2 \frac{1}{2}$ in. pots................. $30 \quad 2.50 \quad 20.00$ 


\section{TREES, SHRUBS AND VINES}

Acanthopanax pentaphylla Five-leaved Aralia

$3^{\frac{1}{2}}$ to $4 \mathrm{ft}$. bushy .... \$ \$. $55 \quad \$ 4.50 \$ 36.00$

Acer dasycarpum (saccharum) Silver-leaved Maple

8 to $10 \mathrm{ft} . \ldots . . . .25$ I I I.50

I8 to $20 \mathrm{ft}$. 3 to 4 in. cal.

6 to 15.00

ginnale Tartarian Maple

6 to 8 ft. XX bushy . . $\quad 2.75 \quad 22.50$

8 to ro ft. XX bushy... $5.50 \quad 50.00$

platanoides Norway Maple

I2 to $14 \mathrm{ft}$. 2 to $2 \frac{1}{2}$ in. cal. . $3.50 \quad 30.00$

$\mathrm{I} 4$ to $16 \mathrm{ft} .2 \frac{1}{2}$ to 3 in. cal. . $5.50 \quad 50.00$

16 to $20 \mathrm{ft} .4$ to 6 in. cal. . .

16.50 to 27.50

var. Schwedleri Schwedler's Maple

14 to 16 ft. 2 to 4 in. cal. 6 to 8.50

rubrum Red or Swamp Maple

$$
6 \text { to } 8.50
$$

3 to 4 in. cal. . .

6 to 8.50

Actiniơia arguta Silver Vine

Akebia quinata

4 yr. XX strong . . $\quad 1.25 \quad 10.00$

Ampelopsis tricuspidata veitchil Boston Ivy

$$
2 \text { yr. . . . . . . . } 50 \quad 3.5^{\circ}
$$

Aristolachia macrophylla (sipho) Dutchman's Pipe

$$
5 \text { yr...... } 1.50
$$

Azalea arborescens Fragrant White Azalea

I to $\mathrm{I} \frac{1}{2} \mathrm{ft}$. bushy .... 2.25

2 to $2 \frac{1}{2} \mathrm{ft}$. bushy .... 3.00

$2 \frac{1}{2}$ to 3 ft. bushy .....

kaempferi Kaemper's Azalea

12 to 15 in. .......... $2.00 \quad 17.50$

15 to 18 in. . . . . 2.7525 .00

lutea (calendulaceae) Flame Azalea

3 to $3 \frac{1}{2} \mathrm{ft}$. . . . 4.50

pontica Ghent Hybrids

It to $2 \mathrm{ft.}$........... 2.7525 .00

2 to $2 \frac{1}{2} \mathrm{ft} . \ldots . . .24 .00 \quad 36.00$

We can furnish the following Ghent Hybrids:

Bouquet de Flore Rose with white stripe

18 to 24 in.

Coccinea speciosa Clear orange red

18 to 24 in.

Daviesil Cream white, yellow lip, fragrant and early

18 to 24 in.

24 to 30 in.

Gloria Mnndi Clear orange

I 8 to 24 in.

Guelder Rose Pink, yellow lip

15 to 18 in. 
Pallas Bright red

Each 10

I 8 to 24 in.

Sang de Gantbruges Rich carmine red

I 8 to 24 in.

Unique Orange

I8 to 24 in.

mollis var. Hollandia Yellow, flushed with pink

15 to 18 in. ..... $\$ 4.00 \$$

I $\frac{1}{2}$ to $2 \mathrm{ft} . \ldots \ldots . . .500$

2 to $2 \frac{1}{2} \mathrm{ft}$. . . . . 6.00

vaseyi Southern Pink Azalea

I5 to I8 in. ..... $2.00 \quad$ I7.50

2 to $2 \frac{1}{2} \mathrm{ft} . \cdots \cdots 3 . . .30$

viscosa White Swamp Azalea

2 to $2 \frac{1}{2} \mathrm{ft}$. $\quad \dot{x} \cdot \begin{array}{lll}2.50 & 22.50\end{array}$

3 to $6 \mathrm{ft}$. XX heavy coll. clps.

$$
4 \text { to } 6.00
$$

Berberis thunbergil Japanese Barberry

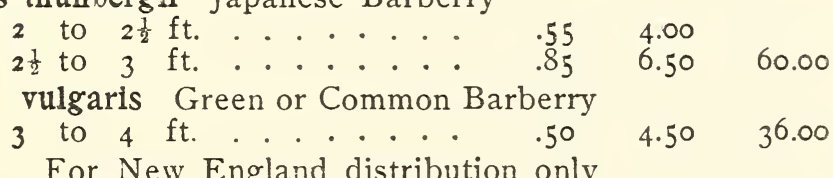

For New England distribution only

Betula papyrifera Paper or Canoe Birch

I4 to I6 ft. ...... $6.00 \quad 50.00$

Calycanthus floridus Pineapple Shrub

$\mathrm{I} \frac{1}{2}$ to $2 \mathrm{ft}$. X heavy ..... . . . $50 \quad 5.00$

Caragana arborescens Siberian Pea Tree

3 to $4 \mathrm{ft}$........ $1.00 \quad 7.50$

Carpinus caroliniana American Hornbeam

Io to I $2 \mathrm{ft}$...... 8.0065 .00

Castanea pumila Chinquapin

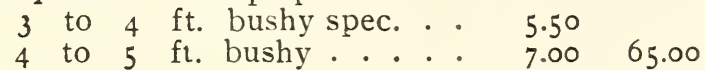

Cercidiphyllum japonicum

6 to 8 ft. bushy ... 2.75

Chionanthus virginica White Fringe

$\begin{array}{lllll}4 & \text { to } 5 & \mathrm{ft} \text {. XX bushy spec. } & 3.50 & 30.00 \\ 5 & \text { to } 6 & \mathrm{ft} . & \text { "6 }\end{array}$

Clematis paniculata Japanese Virgin's Bower

$$
3 \text { yr. strong... . . . } 65 \quad 5.50
$$

Clethra alnifolia Sweet Pepper Bush

$\mathrm{I} \frac{1}{2}$ to $2 \mathrm{ft}$......... 504.50

2 to 3 ft. bushy . . . $\quad .55 \quad 5.00$

Cornus alba (Siberica) Red-twigged Cornel

5 to $6 \mathrm{ft}$........ $\quad .50 \quad 4.50$

Cornus amomum (sericea) Silky Cornel

5 to $6 \mathrm{ft}$........ $50 \quad 5.50$

6 to 8 ft. . . . . . . 857.00

controversa Chinese

8 to Io ft. spec. . . II.jo

florida Flowering Dogwood

6 to 3 ft. bushy $\ldots . .31 .25$ 10.00 


\section{Each 10}

Cornus kousa Japanese Flowering Dogwood

$5 \frac{1}{2}$ to $6 \mathrm{ft}$. bushy .... \$2.75 \$ \$

mas Cornelian Cherry

2 to $2 \frac{1}{2} \mathrm{ft}$. bushy .... $.55 \quad 500$

paniculata Panicled or Gray Dogwood

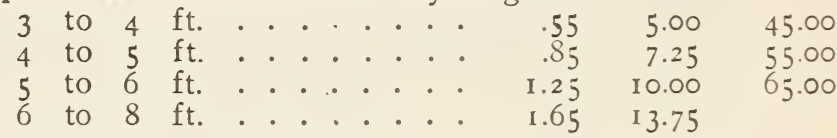

stolonifera Spreading Red Ozier

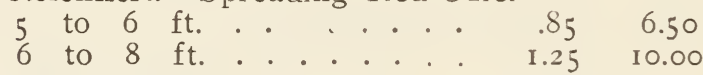

Crataegus arnoldiana Arnold's Hawthorn

6 to $7 \mathrm{ft}$. cut back . . . $3.50 \quad 32.00$

7 to $8 \mathrm{ft}$. " . . . $4.50 \quad 40.00$

8 to $9 \mathrm{ft}$. " . . . 5.50

This is one of the rarest and most beautiful of all Hawthorns. It has large white flowers in early spring. Even the young trees offered by us bear quantities of large round edible scarlet fruits in August and September, and, later, the substantial leaves turn a beautiful scarlet. A beautiful small flowering tree, suitable as a specimen, for planting in groups on the edges of woods, or near the sea.

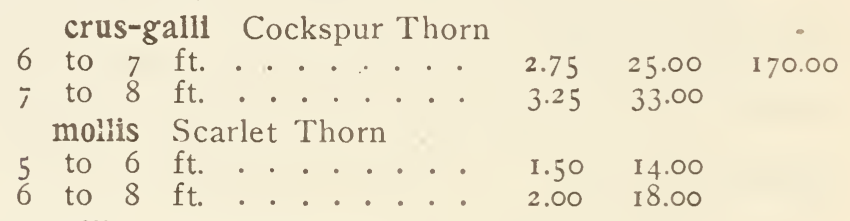

Deutzla gracilis Dwarf Deutzia

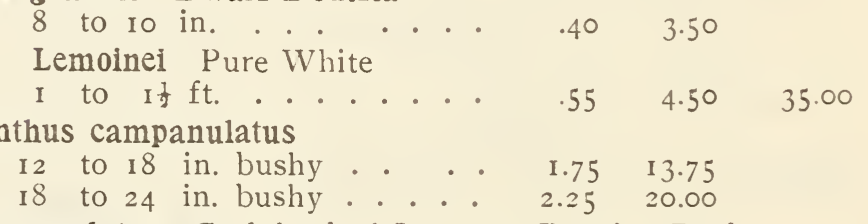

Enkianthus campanulatus

Evonymus alatus Cork-barked Japanese Burning Bush

6 to 7 ft. spec..... 4.5040 .00

7 to $8 \mathrm{ft}$ " " . . . 6 to 13.50

8 to $10 \mathrm{ft}$. ". 13.50 to 22.00

Exochorda grandiflora Pearl Bush

2 to $3 \mathrm{ft}$........... $55 \quad 45.0$

Fagus americana American Beech

5 to $6 \mathrm{ft}$....... $4.50 \quad 33.00$

Forsythia intermedia Golden Bell

3 to $4 \mathrm{ft} . \ldots . . . .6550$

primulina

2 to $3 \mathrm{ft}$......... 1.25

europaea European Forsythia

2 to $3 \mathrm{ft} . \ldots \ldots . . .25$

suspensa Weeping Golden Bell

3 to $4 \mathrm{ft}$.......... $55 \quad 4.50 \quad 35.00$ 


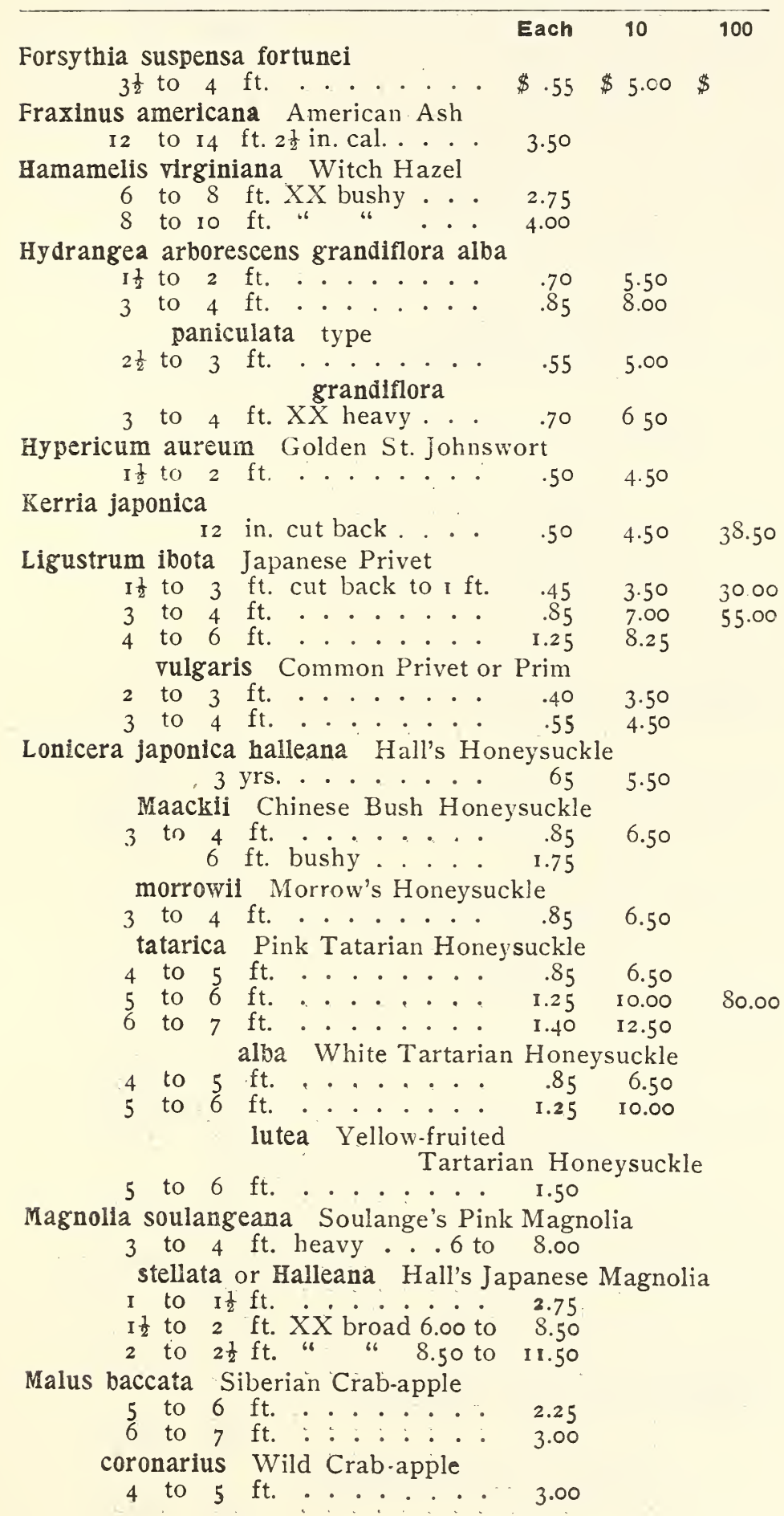


Malus floribunda Flowering Crab

\section{Each 10}

100

3 to $4 \mathrm{ft.} \cdots \cdots . \$ 1.75 \$ \$$

4 to $5 \mathrm{ft}$.

7 to 8 ft. XX heavy spec.

tr. pl. I921 16.50 to 27.50

atrosanguinea Red-fowered Crabapple

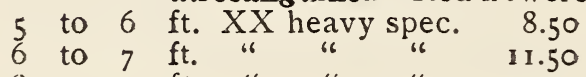

8 to $10 \mathrm{ft}$. " " 16.50 to 27.50

halliana parkmanni

Parkman's Double Flowering Crab-apple I $\frac{1}{2}$ to $2 \mathrm{ft}$. cut back

$$
\begin{array}{lll}
\text { tr. pl. } 1921 & 1.25 & 10.00
\end{array}
$$

ioensis fl. pl. Bechtel's Double Flowering Crab

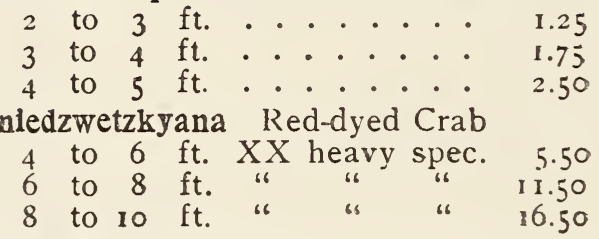

Myrica cerifera Bayberry

$$
\text { I8 in. bushy ... . } \quad .55 \quad 5.00
$$

\section{Phlladelphus coronarius Mock Orange}

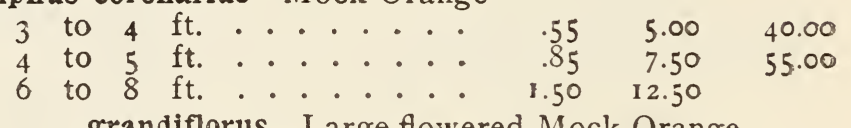

grandiflorus Large-flowered Mock Orange

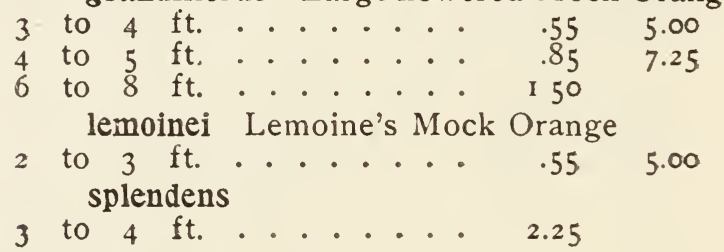

Photinia villosa

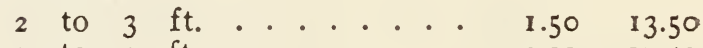

3 to $4 \mathrm{ft} . \ldots . .2 .00 \quad 17.50$

Potentilla fruticosa Veitchil Veitch's White Potentilla

12 to 18 in. bushy .... $.85 \quad 7.25$

parvifolia Deep Yellow Potentilla

18 in. bushy ... $.85 \quad 7.25$

A charming little shrub for use in the rockery

Prunus serrulata sachalinensis (Sargentii) Sargent's Cherry

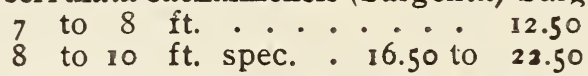

Pyracantha coccinea (Crataegus pyracantha) Fire Thorn

Rhamnus catharticus Buckthom

$$
12 \text { in. bushy } \ldots .11 .35 \quad 12.50
$$

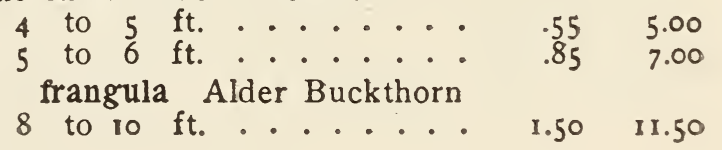


Rhodora canadensis Rhodora

Each $10 \quad 100$

12 to 15 in. ...... \$1.50 \$12.50 \$

Rhodotypos kerrioldes White Kerria

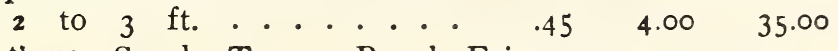

Rhus cotinus Smoke Tree or Purple Fringe

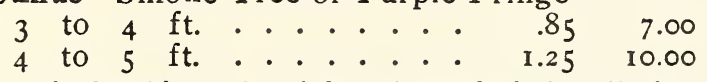

Rosa Alberic Barbier A wichuraiana hybrid climber; glossy foliage and large deep cream flowers late in June
2 to $3 \mathrm{ft}$. spr.
$.75 \quad 6.00$

American Pillar Climber of strong growth with rich glossy foliage and huge clusters of large, cherry-colored flowers

$$
2 \text { to } 3 \mathrm{ft} . \cdots . . . . .75 \quad .00
$$

Apple Blossom Dawson Hybrid

$$
3 \text { to } 4 \text { ft. ...... } 2.75
$$

arnoldiana Arnold's Rose Dawson Hybrid

$$
2 \text { to } 3 \mathrm{ft} \text {........ } 3.50
$$

Dawson A Dawson hybrid climber of rambler habit. Flowers semi-double, deep pink in large clusters. Early

$$
\begin{aligned}
& \text { I to } \mathrm{I} \frac{1}{2} \mathrm{ft} . \ldots . . . .75 \quad 6.00 \\
& 2 \text { to } 3 \mathrm{ft} \text {.......... } 1.25 \quad 10.00
\end{aligned}
$$

Daybreak A Dawson hybrid. A climber with glossy foliage and large clusters of single deep salmon pink flowers in July

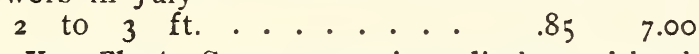

Dr. Van Fleet Strong growing climber with glossy foliage and large double shell pink flowers in early July
I to 2
ft. 2 .
.75
2 to 3
1.50

exceisa Climbing wichuraiana hybrid bearing clusters of double brilliant red flowers late in season

$$
2 \text { yr. XX... } .756 .00
$$

gallica grandiflora Low bush of spreading habit, with rich foliage, young growth deep red. Flowers large, single pink and very early

$$
2 \text { to } 3 \mathrm{ft} \text {............. } 1.25 \quad 10.00
$$

Goldfinch Yellow climber

$$
2 \text { yr..... } 1.25
$$

Harrison Old-fashioned yellow Rose

$$
2 \text { yr..... } 1.25
$$

Hiawatha Climber, single scarlet flowers, white enter

$$
18 \text { in. strong .... } .75 \quad 6.00
$$

Hugonis Father Hugo's Rose. An upright rose with stems covered in early spring with single clear yellow flowers before the foliage appears

$$
2 \text { yr. str. plants } 2.00 \quad 17.50
$$

Lady Duncan A Dawson hybrid, semi-climber, with rich green, rugosa-like foliage, and large clear, salmon-pink flowers, blooming in late June. Absolutely free from injurious pests

$$
2 \text { yr. str. plants } 2.00 \quad 17.50
$$

Lady Gay Pink climber much like Dorothy Perkins 18 to 24 in. ......... . . 65 6.00 
Rosa lucida

Each $10 \quad 100$

2 to $3 \mathrm{ft}$. . . . . . . . $\$ 5.55 \$ 44.50 \quad \$ 35.00$

alba White wild Rose

I to $\mathrm{I} \frac{1}{2} \mathrm{ft}$. . . . . . . $\quad .55 \quad 4.50 \quad 40.00$

Mme. Plantier Old-fashioned, double-flowered white rose 2 to $3 \mathrm{ft}$......... $1.00 \quad 8.50$

Minnie Dawson Dawson hybrid. Rambler of the Dawson habit, the flowers small double white borne in large clusters

I 8 to 24 in. strong .... . 1.25 10.00

multiflora catheyensis Pink multiflora Rose from China 2 to $3 \mathrm{ft}$........ $1.00 \quad 9.00$

Pauline Dawson A Dawson hybrid climber or pillar rose of good foliage and large single deep pink flowers

It to $2 \mathrm{ft}$. ......... I.25

penzance hybrids Bush roses, hybrids of the popular Sweet Briar, having fragrant pink flowers

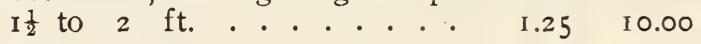

rugosa repens aiba Climbing or creeping white-flowered rugosa hybrid, with glossy foliage and large star-shaped white flowers
2 to $3 \mathrm{ft}$. spread
I. $50 \quad 13.50$

Seashell Dawson hybrid Climber which has glossy foliage and large clusters of large, semi-double pink flowers, blooming in July

$\begin{array}{lllll}\frac{1}{2} \text { to } 2 & \mathrm{ft} \text {. spread..... } & \text { I.25 } & \text { II.50 }\end{array}$

Setigera Prairie Rose climbing

3 to $4 \mathrm{ft}$. . . . . . . . $55 \quad 4.50 \quad 40.00$

William C. Egan A Dawson hybrid, climber, with good foliage and large very double pink flowers. Late June
I to $\mathrm{I} \frac{1}{2} \mathrm{f}$
ft. . . . . .
I.25 10.00
2 to 3
ft. bushy
I. 35
12.50

All the Roses listed above are thrifty two to three-year old plants which were planted from pots last spring, and will lift with good roots

Spiraea callosa alba White Bush Meadow Sweet

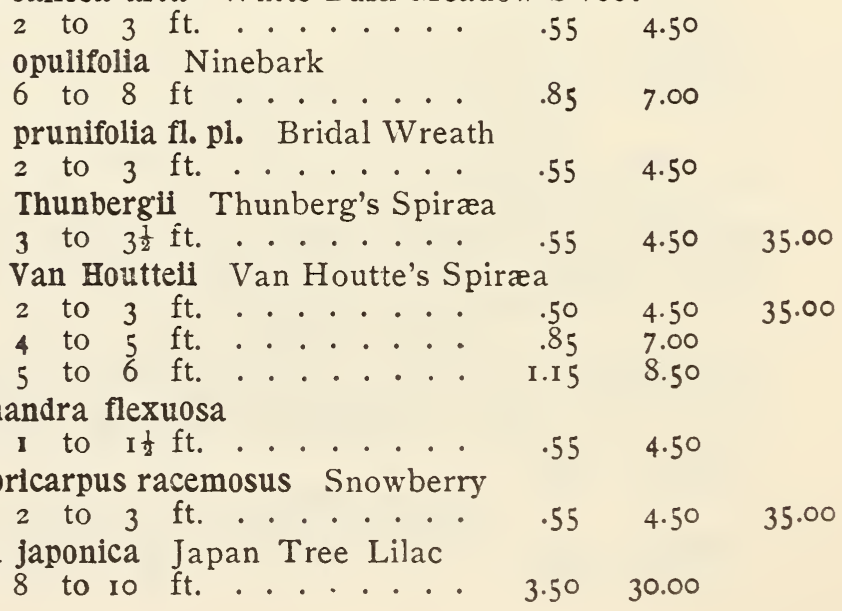




\section{Each 10}

Syringa vulgaris Common Purple Lilac
2 to $3 \mathrm{ft}$.
3 to 4
ft. . . . . . $\$ .55 \$ 4.50$
ft. . . . . . . 857.00
$\$ 40.00$ ar. alba Common White Lilac
2 to $3 \mathrm{ft} . \ldots . . . .5 \quad .55 \quad 4.50 \quad 40.00$ var. Charles $\mathrm{X}$ single dark reddish purple
3 to $4 \mathrm{ft}$. . . . . 2.25
var. Ludwig Spath Deep reddish purple
2 to $3 \mathrm{ft.} . \ldots . . .2 \quad$ I.5O
var. Marie Legraye Single white
2 to $3 \mathrm{ft} . . . .$. I.5O I 2.50 var. Michael Buchner Single deep pink
2 to $3 \mathrm{ft}$. heavy.... I. 65 I 5.00 var. Mme. Lemoine Double white, very fine
2 to 2 ft. ........ I.5O 13.50 var. William Robinson Double Pink
2 to $3 \mathrm{ft}$. heavy..... I.65 15.00

Tilia europaea European Linden Io to $\mathrm{I}_{4} \mathrm{ft} .4$ to $5 \mathrm{in}$. cal.

$$
6 \text { to } 12.00
$$

Ulmus americana American Elm

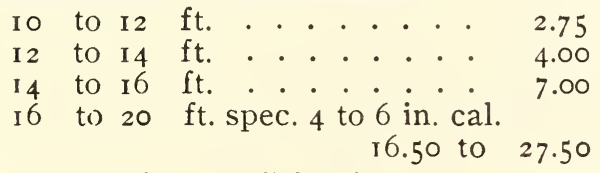

campestris English Elm

$$
\text { r6.50 to } 27.50
$$

I4 to $18 \mathrm{ft}$. spec. 3 to $5 \mathrm{in.} \mathrm{cal}$.

Viburnum cassinoides Withe Rod

$$
\text { I } 6.50 \text { to } 30.00
$$

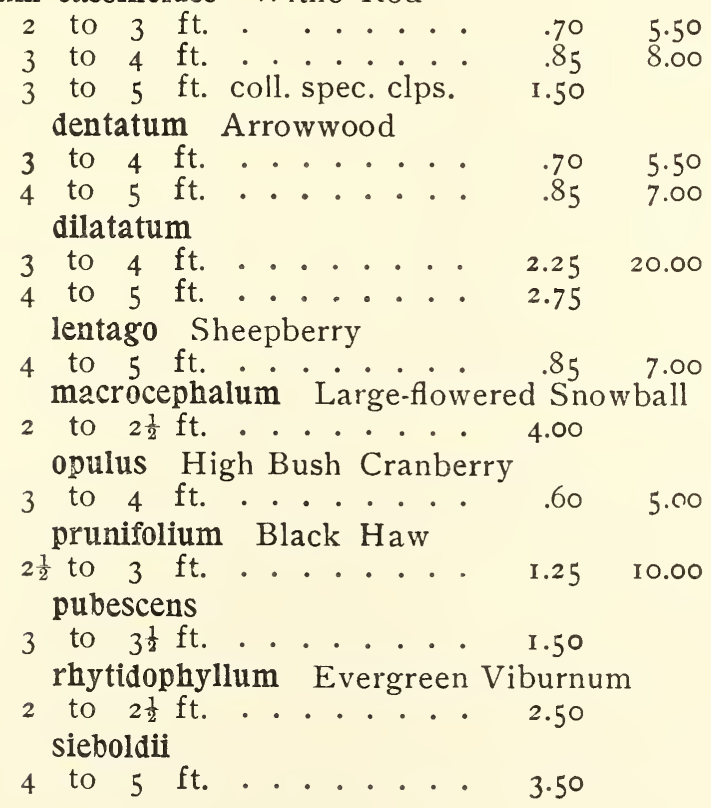



TREES, SHRUBS AND VINES.

Vitus cordifolia Chicken Grape

Each 100 3 yrs. . . . . \$ \$1.25 \$10.00\$

Wistaria chinensis Blue

5 yrs. . . . . . 1.75

multijuga White

5 yrs. . . . . . 1.75

Zenobia puverulenta (Andromeda speciosa)

I $\frac{1}{2}$ to $2 \mathrm{ft} . \ldots \ldots 2.50$ 


\section{HARDY HERBACEOUS PERENNIALS}

Except where noted 25 cents each, $\$ 2.25$ per ten $\$ 16.00$ per hundred

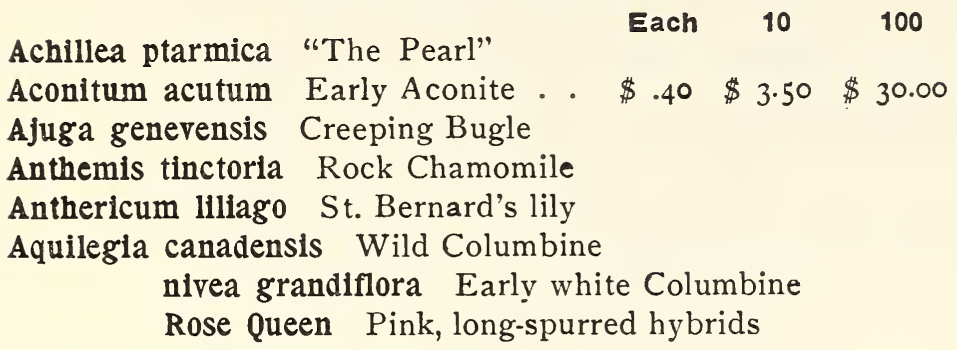

Armeria maritima Sea Thrift

Arabis alpina Rock Cress

Aster alpina Alpine Aster

Climax Tall blue Aster .... $\quad .30 \quad 2.50$

ericoldes White Heath Aster

Feltham's Blue Early, medium height, almost clear blue

Lady Trevellyn White

Novae Angliae rubra Tall growing, intense rose pink shortii Violet blue, medium

tataricus Blue flowers, latest and tallest of Asters

Thompsonii Flowers very large, blue. Low-growing

Baptisia australis False Indigo

Boltonia asteroides False Chamomile

latisquama Pink Boltonia

Campanula carpatica

alba
medium single, white, mauve, pink

Cassia marylandica Wild Senna

Centaurea montana Perennial Cornflower

Cerastium biebersteimil alba White Perennial Cornflower

Chrysanthemum coccineum Pink Daisy

Maximum Shasta Daisy

Uliginosum Giant Daisy

Coreopsis grandiflora Large-flowered Coreopsis

Daphne cneorum Garland Flower

$$
2 \text { yr. clumps .... } 1.00 \quad 8.50
$$

Delphineum chinense Chinese Larkspur, blue

Dianthus barbatus Sweet William red and white

caesius Cheddar Pink

Digitalis plumarius Clove pink

purpurea Purple Foxglove

alba White Foxglove

Erysinum pumilum

Eryngium amethystinum Sea Holly

Eupatorium coelestinum Ageratum-like Eupatorium

Festuca glauca Blue Fescoe Grass 
Gaillardia grandiflora Blanket Flower

\section{Each}

10

100

Geum heldreichii Orange Geum

triflorum Common Avens

Gillenia stipulata

Gypsophila paniculata Baby's Breath

repens Creeping Baby's Breath

Helenium autumnale hoopseil Hoope's Sneezewort

Helianthus maximillianus

Miss Mellish

mollis var. cordatus

multiflorus

orgyalis

rigidus

Hemerocallis dumortierii Dwarf Orange Day Lily

flava Lemon Lily

fulva Tawny Day Lily

thunbergii

Hesperis matronalis Sweet Rocket

Hosta (Funkia) lancifolia Lavender Day Lily

Hypericum adpressum Creeping St. John's Wort

calycinum Rose of Sharon \$.45 \$4 $\$ 400$ \$30.00

Iberis sempervirens Hardy Candytuft

Iris Germanica German Iris

$$
\text { Little Gem Dwarf Candytuft }
$$

Charlotte Patty golden yellow

Fairy Queen white, falls veined in blue

Garrick standards light blue falls a dark blue

Mme. Chereau white, edges of petals blue

laevigata (kaempferi) Japanese Iris

Pallida dalnatica . . . . . . . $35 \quad 3.00 \quad 25.00$

speciosa

lris siberica Siberian Iris

alba White Siberian Iris

orientalis Oriental Iris

Snow Queen White Oriental Iris

Lepachys pinnata Yellow Cone Flower

Liatris scarriosa Blazing Star

Linum perenne Perennial Flax

Lupinus polyphyllus White

$$
\text { Pink }
$$

Lychnis viscaria splendens

Lysimachia nummularia Money-wort

vulgaris Yellow Loosestrife

Lythrum salicaria Purple Loosestrife

Nepeta Mussini

Oenothera fruticosa youngii Dwarf Evening Primrose

Paeonias mixed large clumps ... . $\quad .55$ 
Parthenium hysterophorus Prairie Dock

Each 10

Phlox amoena Dwarf Phlox

paniculata Albion white with pink eye

Antoine Mercie pale lilac, white star in center

Boquet Fleuri pure white, crimson eye, very fine

Bridesmaid White with large rosy center

Czarina fine white, tall and late

Eugene Danzanvilliers lilac rose

Ferdinand Cortez pale crimson, very tall, late

Feu de Monde salmon red, tall, late

Gen. Van Heutz salmon-red with pure white center, large

Hermione dwarf white, large flowers

H. 0. Wijers white, with large red eye. Low

Independence white, medium, early

James Galloway clear red

Lumineaux bright pink with white star, large flowers

Mme. Meuret bright red

Mime. Pape Carpentier white, large flowers, low

Michael Buchner clear pink, large crimson center very tall, late

Mrs. Arnold Turner large flower, white with pink centre, one of best

Mrs. Cook tall, soft magenta pink, very late

Ornament clear rose, very large panicles

Prof. Schlieman pure mauve, crimson

eye, late bloomer

Richard Wallace white, deep crimson eye

R. P. Struthers rosy red, with crimson eye

Rijnstroom clear pink, large flowers, medium height

William Muhle bright pink, tall, late

reptans Creeping Phlox

subulata Pink Ground Phlox

alba white ground Phlox

lilacina lavender ground Phlox

G. F. Wilson bluish lavender $\$ 3.00 \quad \$ 25.00$

suffruticosa Miss Lingard white, earliest of the Phlox

Physostegia virginica False Dragon Head

Platycodon grandiflora Japanese Bellflower

Polemonium richardsonii Jacob's Ladder

reptans Greek Valerian

Rudbeckia hirta Black-eyed Susan

laciniata gr. fl. Golden Glow

subtomentosa 
Sedum acre Stone Crop

lydium roseum

sarmentosum

sexangulare

sieboldii

spectabilis Showy Sedum

stoloniferum (spurium)

Sempervivum globiferum

tectorum Houseleek

Silene maritima Seaside Catchfly

Silphium perfoliatum Cup Plant

Spiraea filapendula Meadow Sweet

japonica see Astilbe Japonica

palmata (Filipendula purpurea)

Deep Pink Meadow Sweet

ulmaria Queen of the Meadows

Stellaria holostea Easter Bell

Stokeisa cyanea Stokes' Aster

Thermopsis caroliniana

Thymus serpyllum coccineum Creeping Thyme

Tradescantia virginica Spiderwort

Trollius europaeus Globe Flower

Tunica saxifraga

Valeriana officinalis Garden Heliotrope

Vernonia noveboracensis Ironweed

Veronica alpestris See V. serpilifolia

gentianoides Gentian-leaved Speedwell

rupestris

spicata Speedwell

var. Maxima Tall Speedwell

serpilifolia Thyme-leaved Speedwell

Viola cornuta atropurpurea 



\section{HOW TO REACH OUR NURSERIES}

By train: Take train from South Station, Boston, or from Worcester and other points west, to Framingham. From Framingham, take train or electric car to Holliston. Upon being notified we will be glad to meet at Holliston any persons desiring to visit the Nurseries. Telephone Natick 345 .

By motor: From Boston the best route is via Newton, Wellesley, South Natick; from South Natick take Elliot Street, to Main Street, Sherborn, thence Main Street, Goulding Street, Mill Street, Fiske Street to the Nurseries.

From Worcester take main route to Framingham, from Framingham follow the street car track to Holliston Centre, turn sharp to left up Central Street, thence Fiske Street to the Nurseries. 